\title{
A New Record on Algal Leaf Spot of Quince from Himachal Pradesh, India
}

\author{
Arti Shukla ${ }^{1}$, S.K. Sharma ${ }^{2}$, Shalini Verma ${ }^{2 *}$ and Bunty Shylla ${ }^{1}$ \\ ${ }^{1}$ Krishi Vigyan Kendra, Kandaghat, Solan (HP) 173 215, India \\ ${ }^{2}$ Department of Plant Pathology Dr. Y.S. Parmar University of Horticulture and Forestry, \\ Nauni, Solan (HP) 173 215, India \\ *Corresponding author
}

\begin{tabular}{|l|}
\hline Ke y w or d s \\
$\begin{array}{l}\text { Quince, Algal leaf } \\
\text { spot, Cephaleuros } \\
\text { species. }\end{array}$ \\
\hline Article Info \\
\hline $\begin{array}{l}\text { Accepted: } \\
28 \text { August } 2017 \\
\text { Available Online: } \\
\text { 10 September } 2017\end{array}$ \\
\hline
\end{tabular}

\section{Introduction}

The quince (Cydonia oblonga) is the sole member of the genus Cydonia in the family Rosaceae. It is a small deciduous tree that bears a pome fruit, similar in appearance to a pear, and bright golden-yellow when mature. Throughout history the cooked fruit has been used as food, but the tree is also grown for its attractive pale pink blossoms and other ornamental qualities. Quince is used to prepare jams, jellies, and puddings, as well as a side dish or a breakfast food. Different countries use quince in different ways, often using the juice as a flavouring agent. However, the real benefit of quince is eating the skin and the fleshy fruit, since it is packed with beneficial nutrients, including vitamins, minerals, phenolic compounds, antioxidants and dietary fibre. Besides being a readily available and delicious fruit, quince is also valued because of its important place in human health. Quince is used as a dwarfing rootstock for pear, depending on the scion desired and characteristics of the production area. Quince is a good rootstock for the Comice pear, demonstrating high yield efficiency and vigour. A factor which limits the broad use of quince as a pear rootstock is poor compatibility with the popular scion 
Bartlett. Of the various rootstocks of quince, Quince BA-29 is most preferred one as it is tolerant of heavy soils, wet soil, and root lesion nematode, with good resistance to crown gall and has moderate tolerance to pear decline. Less desirable traits of the rootstock include low susceptibility to chlorosis and fire blight, and a fair anchorage rating, due to the quince shallow root system (Reil et al., 2007).

Quince is a hardy tree and very less susceptible to diseases. However, in Himachal Pradesh, during disease survey, quince BA 29 rootstocks planted at progeny cum demonstration orchard, Patta Mahlog of Department of Horticulture were found infected with algal leaf spot caused by Cephaleuros sp. In most cases Cephaleuros is mistaken for a fungus, because the symptoms show erect, yellow to red filaments and hairs like a fruiting body that is raised on the leaf surface, which matches the characteristics of rust fungi (Marlatt and Alfieri, 1981). The identification of Cephaleuros can be based on morphological characteristics, although they do not provide definitive separation to distinguish between the species. According to Thompson and Wujek (1997) the features most valuable in determining the species are: (i) thallus growth habit, (ii) manner of bearing head cell or sporangiate laterals, and (iii) the kinds of lesions produced.

\section{Symptoms}

Algal leaf spot is a foliar disease most commonly seen in warm humid climate or in greenhouse conditions. Initially the plants perform well but soon after rainy season in September 2016, leaves of some of these rootstocks exhibited symptoms of algal leaf spoton adaxial surface especially in plants growing under trees. The spots were circular or blotchy in shape, 1-5 $\mathrm{mm}$ in size and were somewhat raised from the plant surface. The edges of the spots were wavy or feathered. They varied in colour from a crusty grey- green to yellowish orange (Fig. 1). However, in October 2016 when the algae are reproducing, the spots took on a crusty, redbrown appearance due to the production of reddish, spore-producing structures. The severity of the disease was rated 15-20 per cent on 0-5 scale. Though often not much serious, the Cephaleuros sp. cause indirect damage to the plants due to reduced leaf photosynthetic area.

\section{Pathogen}

The leaves were brought to the laboratory for microscopic examination of algal structures viz., sporangiophore, head cell and sporangiate laterals (suffultory cell and sporangium) which characterize Cephaleuros sp. Slides were prepared using sterile distilled water as mounting medium. Images of micromorphological structures were captured under a Magnus ICON trinocular phase contrast microscope with a CIS-400-C digital camera. Sporangiophores forming head cell with sporangia on the top (Fig. 2). Also produce sporangiate laterals i.e. sporangia and suffultory cells. Sporangia were elliptical in shape, dark brown in colour.

The sporangiophores were sparsely produced on the upper leaf surface, solitary or in a tuft (Fig. 3). Algal structures were measured using Magnus Pro Image Analysis Software (100X), obtaining the average of 20 measurements for each structure. Measurement of the sporangiophores varied from 305.3-670.4 x 11.1 -19.2 $\mu \mathrm{m}$ (Av. 472.3 $\mathrm{x} 14.5 \mu \mathrm{m})$, sporangia from 22.4-32.8 x 16.8$23.07 \mu \mathrm{m}$ (Av. $27.6 \times 19.9 \mu \mathrm{m}$ ) and that of head cell from 30.2- 57.4 x 29.4- $56.2 \mu \mathrm{m}$ (Av. $43.6 \mathrm{x} 42.5 \mu \mathrm{m}$ ). The number of septa of sporangiophores varied from 4-8. The pathogen was identified as Cephaleuros virescens on the basis of the morphological features and it has been agreed with the description of Vasconcelos et al., (2016) and Thompson and Wujek (1997). 
Fig.1 Symptoms of algal leaf spot on quince

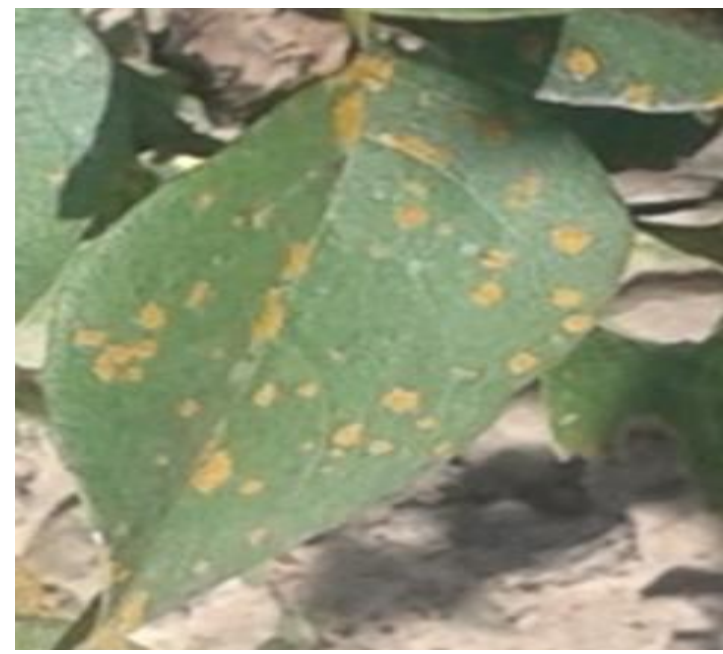

Fig.2 Algal structures (SP- Sporangiophore, HC- Head cell, SC- Suffultory cell and SSporanium) of Cephaleurosvirescens

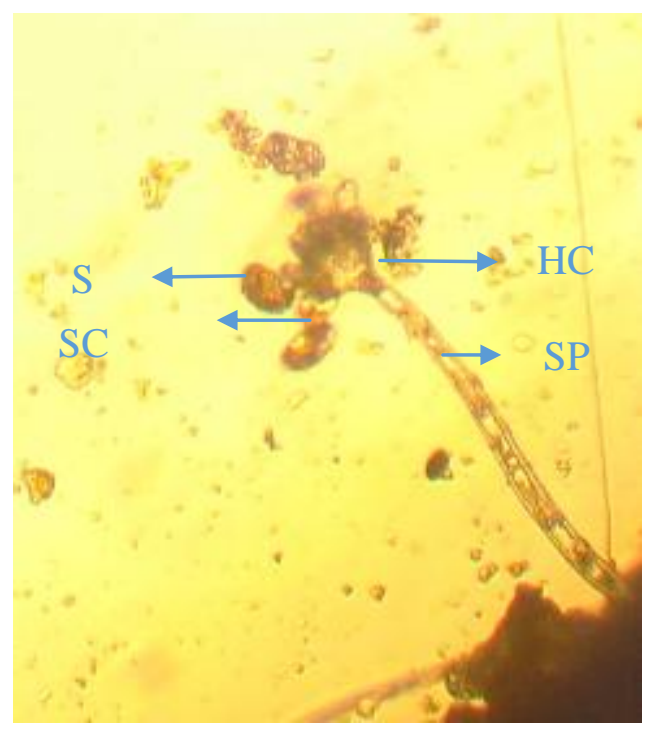

Fig.3 Sporangiophores with sporangia

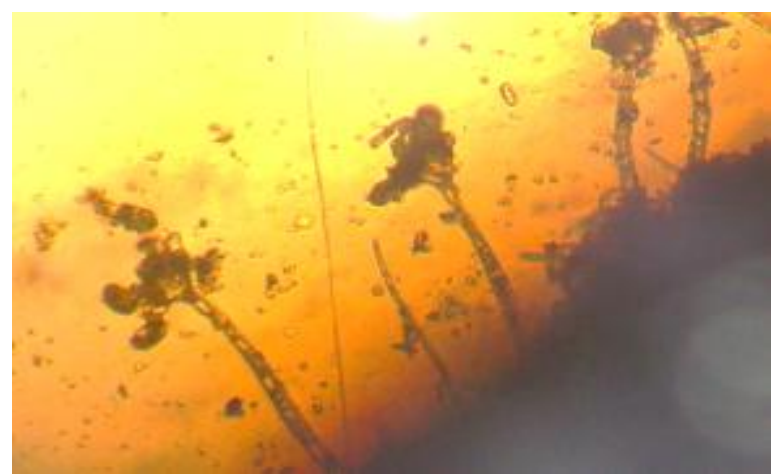




\section{Results and Discussion}

Cephaleuros species are found in tropical and subtropical climates, in all continents and probably allislands between about $33^{\circ} \mathrm{N}$ and $33^{\circ} \mathrm{S}$ of the equator, provided the temperature and humidity are suitable for their growth and reproduction.

On leaves, symptoms vary according to the Cephaleuros-host species combination.

Species of Cephaleuros are very common on the leaves of such economically important tropical trees and shrubs as tea (Camellia sinensis), kava (Piper methysticum), pepper (Piper nigrum), magnolia (Magnolia grandiflora), coffee (Coffea arabica), oil palm (Elaeis guineensis), avocado (Perseaa mericana), vanilla (Vanilla planifolia), acacia (Acacia auriculiformis), mango (Mangifera indica), breadfruit (Artocarpus altilis), guava, coconut (Cocos nucifera), cacao (Theobroma cacao), as well some citrus (Citrus spp.) cultivars (Joubert and Rijkenberg, 1971; Holcomb,1986;Paracer and Vernon, 2000;Sunpapao and Pitaloka, 2015; Thomas et al., 2016 and Vasconcelos et al., 2016).

There is no report of the Cephaleuros virescens on quince from India. Hence, this constitutes the first report of C.virescens on quince from Himachal Pradesh, India.

\section{References}

Holcomb, G.E., 1986. Hosts of the parasitic algae Cephaleuros virescens in Louisiana and new hostrecordsfor the continental United
States. Plant Disease 70:1080-1083.

Joubert, J.J., and Rijkenberg, F.H. 1971. Parasitic greenalgae. Annual Review of Phytopathology9: 45-64.

Marlatt, R.B., and Alfieri, S.A. 1981. Host of Cephaleuros, a parasitic alga in Florida. Proceeding of Florida State Horticulture Society 94: 311-317.

Paracer, S., and Ahmadjian, V. 2000. Symbiosis: An Introduction to Biological Associations. Oxford: Oxford University Press. p. 165.

Reil, W.O., Ireland, J. and Elkins, R.B. 2007. Propagation and Rootstock Selection. Pages 33-44. In: Pear Production and Handling Manual. University of California Agriculture and Natural Resources Publication, 3483p.

Sunpapao, A., and Pitaloka, M.K. 2015. A new record of plant parasitic green algae, Cephaleuros diffusus (Trentepohliaceae, Chlorophyta), on Acacia auriculiformis hosts in Thailand. Biodiversitas 16: 116120.

Thomas, B.T., Thomas, V.P., Bhagya, M.V., Nair, S.S., Rajan, Reshma and Saranyamol, S.T. 2016. New Record of Phytoparasitic Alga, Cephaleuros diffusus Thomson \& Wujekin (Trentepohliaceae, Chlorophyta) on Artocarpusincisus (Thunb.) L.F., Kerala, India. International Journal of Modern Botany 6: 37-40.

Thompson, R.H., and Wujek, D.E. 1997. Trentepohlliales: Cephaleuros, Phycopeltis and Stomatochroon, Morphology, Taxonomy and Ecology. 1st ed. Enfield Publishing and Distribution, USA, 149p.

Vasconcelos, C.V., Pereira, F.T., Galvao, C.D.S. and Carvalho, D.D.C. 2016. Occurrence of algal leaf spot (Cephaleuros virescens Kunze) on avocado in Goias State, Brazil. Summa Phytopatholgy 42: 108.

\section{How to cite this article:}

Arti Shukla, S.K. Sharma, Shalini Verma and Bunty Shylla. 2017. A New Record on Algal Leaf Spot of Quince from Himachal Pradesh, India. Int.J.Curr.Microbiol.App.Sci. 6(9): 31033106. doi: https://doi.org/10.20546/ijcmas.2017.609.382 